\title{
Index of APSA Reports in PS, September 1994-June 1995
}

Article

American Political Science Review

Jones Selects Finifter as APSR Editor

Lichbach Named Book Review Editor

Report of the Managing Editor of the American Political Science Review, 1993-94

Ada Finifter to be APSR Editor

Issue

Page

September $1994 \quad 591$

September $1994 \quad 592$

December $1994 \quad 759$

December $1994 \quad 748$

December $1994 \quad 733$

December 1994

Travel Grants for International Scholars Attending the Annual Meeting

Annual Meeting-1995

Verba Appoints Katzenstein and Katzenstein 1995 Program Chairs

A Call for Papers

New Headquarters Hotel in Chicago for APSA Annual Meeting

Foreign Student Travel Grants for 1995 APSA Annual Meeting

Awards

APSA Establishes the Ithiel de Sola Pool Lectureship

The Charles E. Merriam Award Reinstated

Association Distributes Annual Awards

Contributions to Ensure the Continuation of the Victoria Schuck Award

APSA Awards Presented at 1994 Annual Meeting

Putnam Named First Ithiel de Sola Pool Lecturer

Committees

Advisory Opinion from Ethics Committee on

Notification of Job Applicants When Positions

Are Filled

Nominating Committee Welcomes Suggestions

APSA Committees

Congressional Fellowship Program

Congressional Fellowship Program Alumni Name Daniel Patrick Moynihan, Outstanding Legislator, 103rd Congress

Congressional Fellowship Program Announces 1994-95 Competition Winners

Forty-Second Class of Congressional Fellows Begins 1994-95 Program

Report on the Congressional Fellowship, 1993-94 and 1994-95

Former German APSA Congressional Fellows Meet in Bonn

Council

Council Lifts South Africa Ban

APSA Council Minutes, April 1994

APSA Council Minutes, August 1994

Council Confirms 1996 Program Committee

Dissertations

Doctoral Dissertations in Political Science

Additional Dissertation Listing

Executive Director

Report of the Executive Director

Gopher Report

APSA Gopher Server Up and Running

APSA Gopher Report

APSA Gopher Report

Governing Rules

Annual Business Meeting Rules

International Political Science

Dutch Students Participate in APSA Program on American Politics

Live from Washington: Distance Learning in Russia

USIA Supports Summer Institutes on the American Political System

$\begin{array}{ll}\text { September 1994 } & 596 \\ \text { September 1994 } & 604 \\ \text { March 1995 } & 124 \\ \text { June 1995 } & 259\end{array}$

September $1994 \quad 590$

September $1994 \quad 590$

December $1994 \quad 734$

December $1994 \quad 743$

December $1994 \quad 818$

June $1995 \quad 255$

September $1994 \quad 596$

December $1994 \quad 738$

March $1995 \quad 166$

September $1994 \quad 587$

September $1994 \quad 587$

December $1994 \quad 755$

March $1995 \quad 171$

June $1995 \quad 267$

September $1994 \quad 592$

September $1994 \quad 655$

June 1995255

December $1994 \quad 796$

March $1995 \quad 125$

September $1994 \quad 580$

September $1994 \quad 595$

March $1995 \quad 124$

June $1995 \quad 266$

June $1995 \quad 288$

September $1994 \quad 593$

September 1994

December $1994 \quad 751$
December $1994 \quad 814$ 
Membership

APSA Offers Joint Membership

June 1995

Organized Sections

APSA Organized Section News

September 1994

Section News

Section News

Section News

Presidents and Officers

New APSA Officers Elected

December $1994 \quad 748$

March $1995 \quad 135$

June $1995 \quad 268$

APSA Treasurer's Report

December $1994 \quad 748$

Elinor Ostrom Nominated President-Elect

December $1994 \quad 756$

Profession

AAUP and CAUT Censure List

Placement Report: New Political Scientists on the Job

June 1995

September $1994 \quad 653$ Market in 1994

Professional Development

1995 Annual Meeting Short Courses

June 1995

PS Reports

Index of APSA Reports

Listing of Area Studies Organizations

Listing of Organizations Related to the Study of

Political Science

PS Index of Authored Articles

Publications

Publications List

Publications List

Publications List

Publications List

National, Regional and State Association News

Listing of Regional and State Political Science Associations

National Political Science Association

Research Support

1994 Research Support Grants Announced

Women and Minorities

Ralph Bunche Program Suspended for Summer

Association Establishes Graduate Fellowship Program for Native American Students

Participation by Women in the 1994 APSA Meeting

Women's Caucus for Political Science Celebrates Its 25th Year

Atlanta Ralph Bunche Summer Institute Consortium Honored

APSA Minority Fellows Selected

June 1995

September $1994 \quad 587$

September $1994 \quad 634$

December $1994 \quad 769$

March 1995

September $1994 \quad 658$

December $1994 \quad 826$

March $1995 \quad 178$

June $1995 \quad 291$

March $1995 \quad 140$

June $1995 \quad 269$

September $1994 \quad 595$

September $1994 \quad 590$

September $1994 \quad 592$

December $1994 \quad 741$

December $1994 \quad 742$

December $1994 \quad 747$

June 1995264

\title{
The American Political Science Review Book Review, 1991-95
}

\author{
Melissa P. Collie, ${ }^{1}$ University of Texas at Austin
}

This report discusses the operation of the American Political Science Review Book Review during my editorship, 1991-94. In this period the Book Review received more than 6,000 books for consideration. Of these, 940 were selected and reviewed in the September 1992March 1995 issues of the APSR. The Book Review also commissioned review essays on major topics in political science that were written by distinguished scholars including Herbert Kitchelt, regime transformation; David Brady, divided government; Leslie Greene, natural law; James Stimson, public opinion and representation; Jean Elshtain, feminist theory; Elinor Ostrom, the significance of political institutions; David Laitin, political culture; and Allen Buchanan, communitarianism and liberalism.

Two tasks are the most important to the operation of the Book Review: selection of books and of reviewers. This report describes operation of the Book Review in terms of these tasks. A final section considers the interdependence between book and reviewer selection and the way this interdependence affects the quality of individual reviews and that of the Book Review as a whole.

\section{Selecting Books}

To elaborate on the numbers cited and illustrate the current scope of the Book Review, Table 1 